Journal of Education and Vocational Research

Vol. 4, No. 2, pp. 47-59, Feb 2013 (ISSN 2221-2590)

\title{
A Case Study of Instructional Contributions of Community and Government Secondary School Administrators in Pakistan
}

\author{
Asif Khan \\ Karakoram International University, Gilgit, Pakistan \\ asif.khan@kiu.edu.pk
}

\begin{abstract}
The study examined the instructional contribution of a community and government school administrator in Pakistan. While using qualitative tools to generate data, the research exclusively examined the administrators' engagements in such instructional processes as conducting class visits, arranging inschool professional development programs, and contributing to curriculum enrichment. The study noted that as compared to government administrator, the community administrator seemed more active in the instructional processes of his school. The detachment of the government administrator from classroom practices had many implications that also influenced the quality of education in the government school. On the basis of the findings of this study, I maintain that the efficiency of school administrators is contingent upon multiple elements, such as provisions of job related training, introduction of an effective accountability tool, support of instruction oriented educational officials, and contribution of community/parents The study suggested Pakistan should address the above-mentioned elements when defining the instruction-oriented role of school administrators in the country.
\end{abstract}

Keywords: Pakistan; School administrators, Instructional contributions; Community schools; Government schools

\section{Introduction}

Researchers tend to agree that school administrators, whether working in developed or developing countries, have a central role in the qualitative improvement of schools. For example, Chapman (2000) argued that school improvement across the developing countries of Asia is largely contingent upon the administrators' understanding of instructional processes and their ability to transform the available resources into effective educational programs. Despite this realization, there are still a significant number of developing countries, including Pakistan, where the centrality of school administrators has not been acknowledged (Oplatka, 2004). For instance, the last two educational policies of Pakistan have recognized the critical role of school administrators (Khan, 2010), but it has limited this recognition to the rhetoric. The government has not made any genuine efforts that would directly contribute to the development of school administrators. One of the issues associated with the school administrators in developing countries is that these administrators are not adequately prepared to address the educational development of their schools. "There is rarely any formal leadership training and principals are appointed on the basis of their teaching record rather than their leadership potential" (Bush, 2008). As a result, school administrators contribute minimally towards instructional development, especially in those government schools that cater to the educational needs of the majority of the population in Pakistan (Memon, Ali, Simkin, \& Garret, 2000). However, evidence suggests that the private schools in Pakistan, unlike the government schools, have a high quality of education (Andrabi, Das, \& Khawaja, 2008; Khan, 2005). In addition to other factors, Plank (1987) pointed out that the educational quality of developing countries is also contingent upon the quality of school administrators: "The quality of the administration ... remains extremely important" (p.125). Plank's statement reinforces the findings of a number of studies conducted in developing countries (Memon, 2000; Jimenez \& Lockheed, 1995). In these studies, which compared private and government administrators, the researchers noted that the private administrators were more effective in contributing to the academic achievement, instructional, and supervisory processes of their school than their government counterparts. Therefore, this study investigated the role of two Pakistani secondary school administrators-one from a community school and one from a government school. Since limited research focusing on the roles and responsibilities of Pakistani school administrators is available (Rizvi, 2008), this study exclusively examined two administrators and their efforts 
to improve the academic progress of their schools through conducting class visits, arranging in-school professional development programs, and contributing to curriculum enrichment. The study not only examined the instructional contributions of the two administrators, but it also analyzed those structural factors that played an important role in shaping the instructional practices of the two subject administrators.

Context of the Study: The study was conducted in Gilgit, the capital of the Gilgit-Baltistan (GB) region of Pakistan. Officially, GB is a disputed territory between India and Pakistan; however, the federal government takes care of the developmental processes of this region. A local community played a central role in the establishment of the community secondary school, which is also affiliated with an International NonGovernmental Organization (INGO). The INGO has a network of schools across the country, a professional development center, and a higher educational institution where it provides training opportunities to head teachers and teachers. A total of 475 students attended the community school from head start to tenth grade. Students of the community school had an average academic performance on the Board examination. Since education is not free in the community school, students need to pay a reasonable tuition fee. The government secondary school, which is one of the oldest schools of this region, offers education from sixth through tenth grades. Four hundred fifteen students attend this school. Although the students do not pay tuition, they do pay a minimal fee of Rs. 20 ( $\$ 0.23$ cents) as a welfare fund that is utilized for the purchase of such office supplies as stationery, paper, markers, and white board. Students at the government school had a below average performance on the Board examination.

\section{Methodology}

The data for this study were initially generated for a doctoral dissertation. Since qualitative methods offer researchers a wide range of tools for the data collection, such as interviews, direct observations, and document reviews, (Mertens, 2005), I used the case study approach as one of the qualitative methods for this study. Two reasons explain my selection of the case study method: 1) the concept of school leadership has recently gained the attention of policy makers and 2) the study explored how the two different systems (community and government) led the two administrators to differently deal with their instructional responsibilities. Stake (1995) recognized that the case study method is compatible with research exploring a contemporary topic: "A case study is an empirical inquiry that investigates a contemporary phenomenon within its real-life context" (p.13). Likewise, Ogawa and Malen (1991) pointed out that when the research topic has not been the focus empirical investigation, an exploratory case study is a suitable approach. Therefore, the case study method seemed the most reasonable approach for this research. My familiarity with the local educational system and its affiliated schools led to the adoption of a convenience sampling approach to identify the community and government schools. Two school administrators, one from the community school and one from the government school, and four teachers (two from each school) were selected as the subjects of the study. To generate data, the study used three tools: interview, observation, and document review. Since thematic analysis is affiliated with qualitative studies (Constas, 1992), I developed certain themes and then carried out the analysis on the basis of these themes.

\section{Literature Review}

School Administration in Pakistan: Three different kinds of educational systems-private, religious and government-cater to the educational needs of the population of Pakistan. Local/ international NonGovernmental Organizations, wealthy individuals, and communities finance and manage the private institutions. Private schools charge differing fee structures for the education, depending upon the locality and the reputation of institution. Some of these private schools follow the national curriculum, while others have introduced the 0 and A level educational systems. Unlike the private schools, the religious schools depend upon financial support from charities and politico-religious organizations. Everything in religious schools, from the provision of books to shelter and food, is free. The religious schools do not follow the national curriculum; instead, they have their own curriculum, which focuses on religious education. Government schools are the largest service providers of the Pakistani educational system. These schools, which are dependent on funds from the state, follow the national curriculum and the policies developed by the government. Additionally, government schools have a highly centralized organization. Twenty-six percent of Pakistani children attend private schools, one percent attends religious seminaries, and seventy-three 
percent attend government schools (Burki, 2005). Plank (1987) attributed the failure of educational reforms within developing countries to the passive role of school administrators. Many factors, including the recruitment of school leaders and the availability of professional development opportunities, explain the passivity of school level managers in less-developing countries. Simkins, Sisum, and Memon (2001) pointed out that in Pakistan both the private and government sectors follow similar policies concerning the recruitment of head teachers; instead of considering managerial competencies, they give priority to the length of teaching experience. Despite this similarity, research suggests that private administrators employ a more instruction-oriented position than government leaders. Memon et al. (2000) noted that in Pakistan the private school administrators demonstrate a better understanding of curriculum and instruction, human management, and community/school relationship when compared to government administrators.

Because the government school administrators have limited involvement in teaching and supervision (Khaki, 2005; Memon, 2000; Simkins et al., 1998), they tend to be more involved in administrative tasks. Researchers have identified two major reasons for this non-instructional behavior of government administrators: 1) a highly centralized educational system 2) the non-availability of professional development opportunities (Khan, 2004; Simkins et al., 1998). According to Simkin et al. (1998), a centralized and bureaucratic system, which controls the public institutions in Pakistan, provides little opportunity for school administrators to demonstrate efficiency. Similarly, Douglas (1988) noted that in developing countries the "upward looking" behavior is a major hurdle that limits the administrators' willingness to take initiative. As a result, government school administrators are "constantly eclipsed by the drain of bureaucratic compliance demonstrations and inescapable administrative minutiae" (Beatty, 2008. p.138). Jimenez and Lockheed (1995) attributed the efficiency of private administrators in developing countries to administrators' degree of influence in the processes of school related decision-making, such as recruitment of teachers and evaluations. Similarly, Memon et al., (2000) pointed out that the freedom enjoyed by private administrators leads them to become more involved in educational tasks. On the other hand, the limited powers of government administrators prevent them from participating in the hiring and firing of teachers for their schools (Simkin et al., 1998). One of the negative implications of this situation, according to Kandasamay and Blaton (2004), is that government administrators are unable to take disciplinary measures against those teachers with questionable performances. Legotlo and Westhuizen (1996) pointed out that due to the lack of required skills and competencies, government administrators in developing countries are unable to deal with the disciplinary issues of teachers. Khan (2004) suggested that the traditional educators' preparations programs in Pakistan do not enable the administrators to develop competencies, such as modern management, monitoring, and evaluation skills. Khan (2004) added that school administrators in Pakistan are not exposed to a sustained professional development program: "There are some training programs, which provide inservice training to head teachers, but this happens rarely and benefits only a very limited number. This usually takes place with the support of foreign-funded projects" (Khan, 2004, p. 100). Therefore, even with the availability of required human and physical resources, administrators are unable to productively utilize these resources for the educational progress of their schools (Chapman, 2002).

When comparing the characteristics of private and government school administrators in Pakistan, Khaki (2005) noted that the private administrators have certain assets that the government administrators lack such as effective communication skills, strong personality, and a Master's degree in education. Oplatka (2004) stated that the limited training programs of developing countries do not help the school administrators to become instructional leaders; instead, the emphasis is on the managerial and administrative aspects of their job. Similarly, Khaki (2005) asserted that in Pakistan "heads are seen as administrators rather than teachers or educators; they have neither the skills nor the time to engage in teaching or coaching" (p.35). The following excerpt reflects the practices of the majority of Pakistani government school administrators: They rarely supervise other teachers, help them to develop greater self-confidence and better teaching skills, or work with them in other ways... in a typical week they spent twenty-four hours teaching their own classes and substituting for absent teachers, five hours on school administration, four hours on maintaining discipline, three hours on supervising teachers, two hours on preparing lesson plans, and less than an hour on fund raising (Warwick \& Reimers, 1995, p.99). Limited orientation and the non-availability of professional enhancement programs have led the government administrators to develop a minimal understanding of their position. Warwick and Reimers (1995) characterized the Pakistani government school administrators in the following words: "With no clear definition of who they are and what they are supposed to do, schools heads 
are adrift in the educational system ... they were not trained to be leaders, did not see themselves as leaders, and did not act like leaders" (p. 101). One of the implications of this situation is that the practices of administrators have become more authoritative. According to Oplatka (2004), this authoritative behavior is detrimental for upholding the principles of democracy and collegiality because the administrators are "likely to refrain from involving teachers and parents in decision-making, participative leadership, delegation of responsibilities, or major school change initiations" (p.440).

\section{Findings}

The community and government schools shared many similarities. For instance, both the schools were equipped with basic human and physical resources, such as libraries, teachers, the required number of classrooms, and science laboratories. Both of the schools had a typical student-teacher ratio with 25 to 35 students in each class. The two administrators agreed that they have the responsibility of developing an environment that could ensure the delivery of quality education. They also shared a strong understanding that the purpose of education is to prepare children to become responsible citizens. However, the nature of the two administrators' contribution towards the instructional processes of their schools differed. The following sections separately discuss the administrators' involvement in the processes of supervision, inschool professional development programs, and curriculum enrichment.

The Administrator of the Community School: The administrator took charge of the community school in 2005. He and his teachers received a detailed job description upon their appointment; this helped them learn about their responsibilities as well as the school's rules and regulations. The administrator acknowledged the central role of the International Non-Governmental Organization (INGO) and the community in the development of various components of his school. For instance, the INGO was instrumental in the provision of instructional materials, processes of supervision, improvement of quality, appraisal of teachers/administrator, and provision of professional development opportunities. Similarly, the community was helpful in raising funds, enrolling students, building infrastructure, and identifying volunteer teachers for the school. The administrator also reported that a seven member Village Education Committee (VEC) oversaw the operations of the community school. However, the administrator expressed unhappiness with the financial incentives offered by his school. I heard him complaining on many occasions about the inadequate salary package offered to him and his staff: "The volume of our responsibilities is equal to that of the administrators of other government and private schools, but those administrators earn three times more than we do." The administrator added that because of this situation, teachers prefer to join the government schools, a reality that led him to constantly search for volunteers and teachers. The administrator, who had more than thirty years of teaching experience and a B.Ed. degree, had a strong understanding of his managerial and instructional responsibilities. The administrator acknowledged that the INGO with which his school was affiliated provided him with numerous job-related trainings opportunities, such as a Certificate in Educational Leadership and Management [CELM] and a School Leadership Training Program [SLTP]. He added that these programs helped him to develop an understanding about the various dimensions of leadership and management. The administrator further mentioned that these interventions not only motivated him to contribute to the instructional processes of his school, but also led him to appreciate the critical role of parents and communities in the affairs of the school. The administrator of the community school believed that a strong link exists between an effective administration and the instructional development of the school: "For example, a teacher who does not come to school on time causes the education of children to suffer. Therefore, I have the administrative responsibility to tell that teacher about his need to come to school on time." The administrator was not only vigilant about the punctuality of his staff, but he was also very mindful about the regular attendance of students. Therefore, during the observation period, I rarely noticed the late arrival of either teachers or students. However, the teachers of the community school believed that the quality of education depended upon factors other than ensuring the timely arrival of teachers and students.

The teachers expressed their reservations by noting the gaps between the administrator's practices and his claims concerning his contributions towards the instructional processes. One of the teachers commented that their administrator belongs to an older generation of administrators because he had not embraced a more modern approach to school management. Teachers reported that their administrator has limited skills 
pertaining to the academic development of the school. One of the teachers mentioned, "A school administrator needs to be highly qualified...He should understand the modern teaching techniques." The administrator acknowledged that although he tries his best to focus on the instructional processes of his school, some of his managerial tasks divert his attention from instructional responsibilities: "Except for the two classes I teach every day, I spend most of my time taking care of administrative tasks. I also communicate a great deal with students, parents, and members of the community." Because these administrative responsibilities are not all-consuming, the administrator still had ample time to focus on the instructional development of his school. Additionally, the administrator shared some of his administrative responsibilities with his vice principal and other teachers. Since the INGO and community were taking care of such practical matters as the school budget and the purchasing of school supplies, the administrator was free from these administrative responsibilities. Not only did the administrator regularly teach two classes, but he also frequently taught substitute classes. In this way, he kept himself abreast of the instructional processes of his school. However, I did not notice the administrator engaging in proper lesson planning before taking regular classes. The administrator explained his lack of lesson planning by stating that he had been teaching different subjects for many years and no longer needed to prepare lesson plans for each subject he taught. The administrator's protracted association with the teaching profession and his exposure to professional development opportunities helped him to develop a sound understanding about interactive teaching methods and curriculum enrichment. During the shadowing period, I noticed that the administrator would motivate the students to engage in classroom discussions. Instead of depending on information provided by the textbooks, he drew examples from real life situation with the aim of enriching the curriculum. He also encouraged his teachers to find ways to enhance the curriculum of their respective subjects. The administrator shared the following example of how he and his teachers attempt to deepen the education of their students: We take our students on field trips in order to make them understand a particular topic. For instance, when the students studied electricity generation and turbines, they went to an electricity generation unit where a site engineer talked to them about the functions of a turbine. Similarly, when the students studied particular rocks, the class teacher took them to a nearby mountain where the students saw rocks and made their notes.

During the data collection period, I not only observed the administrator's teaching, but I also regularly studied the way in which he conducted class visits and monitored teacher attendance. The administrator defined the purpose of his class visits as "to confirm the presence of class teachers to ensure that classroom time is not wasted and that parents have no complaints about their children's education." During these visits, the administrator did not make any comments about the teaching methodologies of his teachers. When asked why he did not give feedback to his teachers, the administrator replied that he preferred to give feedback at the time of the annual appraisal-a tool that determines the continuity of the teacher's job and increase in salary. The administrator pointed out that the annual appraisal plays an important role in maintaining an ideal learning environment of his school. Two indicators determine the appraisal: 1) quality of teachers' teaching and 2) quality of students' learning. The administrator added that these two broad indicators have sub-categories that examine the numerous dimensions of teaching, such as lesson planning, subject competency, classroom management, teaching techniques, etc. However, the teachers had reservations about the mechanism of the annual appraisal. They noted some gaps, as one of the teachers pointed out: The annual appraisals are not adequate because teachers could be sick on that particular day and not perform well. The head teacher visits the classes, but the intention of his visit is to check the presence of teachers, not to evaluate the performance of the teachers or to provide feedback about methodologies. Teachers' appraisals should be formative. Teachers only receive feedback about their teaching methodologies on the infrequent occasion of teachers' appraisal. Since the administrator remained as a teacher trainer, he encouraged his teachers to enhance their skills and competencies. He mentioned that it is not enough to earn only a Certificate of Teaching (CT) or Primary Teaching Certificate (PTC) degree in order to become a teacher; instead, one needs advance degrees in instruction and pedagogy. He also arranged in-school professional development activities for his teachers. The administrator had a good understanding about the concepts of mentoring and coaching, and this understanding led him to assign an experienced teacher to newly appointed teachers for the development of a mentor/mentee relationship. The teachers had a positive opinion about the professional development endeavors of their administrators. One of the teachers mentioned the following: The headmaster encourages professional development programs within the school through different activities. For instance, if a teacher returns after attending a course or workshop, he invites that teacher to 
share the experience with other teachers...Likewise, if we [teachers] find a good article related to our profession and interest, we share it during recess.

The administrator not only acknowledged the contributions of community towards the academic development of his school, but he also recognized the instruction-oriented support of district educational officials. From the monitoring of instructional processes to the development of school plans and objectives, the educational officials made their services available to the school administrator. During the observation period, I noticed evidence of such instruction-oriented support. For instance, during their school visits, the educational officials would hold detailed discussions with the administrator and teachers about the instructional processes of their school. On one occasion, two educational officials visited the community school; one of the educational officials stayed with the administrator in order to discuss academic matters, and the second official went to a classroom where a newly trained teacher was engaged in reading a story to students in an early childhood education program. After observing the teacher's way of reading the story, the educational official advised the teacher to make the tone of her voice more reflective of the rhythm of the story. The educational official added that in this way the teacher will capture the attention of the children for a longer period of time.

The Administrator of the Government School: The government administrator, who had B.Ed./B.Sc. degrees, more than thirty years of teaching experience, and five years of managerial experience, believed that an individual can either be a good teacher or a good administrator. He defined teaching students and managing schools as two different professions; therefore, one can either be a good teacher or an effective administrator. Additionally, the administrator stated that his expected transfer to another school has minimized his efficiency in terms of his involvement in the instructional affairs of his school. While confirming this statement of the administrator, one of the government teacher's added, "The problem with this administrator is that he is being told that he will be transferring to another school; this is the reason he is not taking an interest in his job." Another teacher pointed out, "since he lacked the disposition and skills needed for an administrator, he did not want to be a principal, but he assumed the responsibility as a result of directives from the higher authorities." The government administrator did not receive any training, orientation, or job description about his position before taking charge of the government school. When asked how he developed an understanding about his instructional and managerial responsibilities, the administrator replied, "I started learning through my own experience. I was not told what I had to do." The government teachers acknowledged the honesty of their administrator, but they also reported that the administrator lacked numerous skills related to instruction and pedagogy. One of the teachers said, "one cannot run a school only with honesty. An administrator needs to be skillful, competent, and visionary. Unfortunately, our administrator lacks these qualities." Government teachers further noted that their administrator runs the school in a traditional way that is not compatible with the modern era. While commenting on the administrator's lack of current knowledge, one of the teachers stated the following: "He [administrator] is a simple B.Sc. and B.Ed. Teacher, but things have changed in schools. A simple B.Sc./B.Ed. is not enough to run a school in an efficient manner. A university degree in the field of educational management is important to run today's schools." When asked how the lack of appropriate knowledge affected the practices of their administrator, the teachers described the minimal involvement of their administrator in the instructional processes. However, the administrator, unlike his teachers, did not seem concerned about his lack of training opportunities; instead, he argued that his many years in education had prepared him to become a competent school leader.

The administrator mentioned that he fulfills his educational responsibilities through proper planning. "By planning, I mean what I have to do during this academic year and what activities I have to conduct during different months and weeks." However, the observation period revealed that the administrator primarily carried out his job without any planning or systematic approach. For example, he did not develop an annual calendar of activities for either his teachers or students; instead, he preferred to carry out his responsibilities on a need basis. Moreover, the teachers had different perceptions of the administrator's instructional competencies. The teachers believed that they were capable educators; they implied that the administrator failed to take advantage of their expertise. One of the teachers reported, "Teachers in the government schools effectively fulfill their responsibilities, but the success of the school depends on the principal and his visionary qualities ... if he is competent, teachers and students will be competent. If he is not competent, then 
a disastrous learning situation will develop." The administrator claimed that he takes substitute classes, but the school register that maintained the list of substitute teachers did not confirm his claim. Also, I did not notice him teaching substitute classes during the observation period. Although the school contained a library and science laboratories, these facilities were inaccessible to the students. When I inquired about the closure of the school's science laboratories, the administrator did not provide a reasonable explanation; instead, he simply said, "This is how the government schools are being operated." One of the teachers made the following comment about the closure of the school laboratory: "Whenever I need a particular piece of equipment from the laboratory [science], the person who takes care of the laboratory is not there. Sometimes the laboratory keys are not there ... Likewise, the relevant teachers do not possess the necessary teaching kits ... I think every teacher should have his own teaching kit." The administrator reported that he frequently visits the classrooms and observes the teaching methodologies of his teachers. During the three-month shadowing period, the administrator made only one visit. Instead of paying attention to the teaching and learning, he seemed more interested in ensuring the presence of teachers in the classroom. Despite this concern about teacher attendance, I noticed the absence of teachers on numerous occasions; the administrator was helpless to address this issue. On one occasion, a health and physical education instructor informed the administrator about the non-availability of a certain number of teachers. The administrator expressed his displeasure by saying, "these teachers have turned the school into a hotel; they come to school whenever they like, and they leave the school whenever they like."

The government teachers, who wanted their administrator to visit classrooms, attributed the disengagement of the administrator from the classroom practices to his lack of interest in the learning process. In this regard, one of the teachers reported the following: Due to my request, he [the administrator] began limited class visits, but the purpose of these visits is not constructive. He does not provide any feedback to the teachers. For the last two years, he has not come to my class; even on a single occasion... He needs to know what is going on in classes and whether or not the teachers have covered the syllabus of their respective subjects. Another teacher mentioned the following: He should come to our classes at least once a week. He needs to check the teaching methodologies of teachers and provide us with feedback about our methods of teaching. He needs to send a message to both teachers and students that their headmaster is a vigilant one. Instead of visiting classes, the administrator had asked a physical education instructor and vice principal to assume this responsibility. He defined their task as ensuring the presence of teachers, not as providing feedback to the teachers about their teaching methodologies. Prior to assuming the leadership position of the school, the administrator had earned recognition as one of the best science teachers of the region. However, the teachers reported that their administrator did not use his teaching competencies either to enhance the skills of other science teachers or to bring improvements to the teaching of science subjects. When I questioned the administrator about sharing his own competencies and arranging in-school professional development programs, he replied that his government school did not have the mechanism to assess the needs of the teachers and, therefore, to arrange suitable professional development sessions for teachers. Additionally, the administrator asserted that government schools only appointed trained teachers; as a result, he did not believe that these teachers required further in-school training sessions: "I could only be motivated to provide guidance and help to the teachers if they were untrained. Since appointing untrained teachers is not a practice and I get trained teachers, why would I provide them with further training?" One of the teachers reported that after attending a course on "Low Coast No Cost Material," he wanted to share his insights with other teachers, but his administrator did not encourage him to do so.

The administrator was not only indifferent about in-school professional enhancement opportunities for his staff, but he was also not proactive in enriching the curriculum. The administrator explained that since the government controls the curriculum, he had no role in enriching the curriculum: "I don't have any role in curriculum development or enrichment. We are provided specific curricula by the state, and we have to follow these curricula. Neither the administrator nor the teachers are allowed to digress from these curricula." However, the administrator added that he motivates his teachers to develop lesson plans for their respective subjects: I ask the teachers to teach their respective subjects through lesson planning. I provide them with proper guidance about the lesson planning. I tell them how one can use audio-visual aids in lesson planning. In our school, all teachers prepare lesson plans for their subjects. Sometimes they share their lesson planning with me. If have time, I see the plans. The teachers did not agree with their administrator's claim about encouraging them to prepare lessons. For example, during a staff meeting, some of the teachers 
complained to their administrator that the majority of the teachers did not create lesson plans; the administrator, however, did not respond to this observation. One of the teachers reported that curriculum enrichment and lesson planning are not compatible with the practices of his administrator. He added, "Our administrator does not even know whether or not we teachers have completed our syllabus. 'In the past, we had an administrator who would ask us to provide information about our progress with the syllabus. Those teachers who had not covered the syllabus in a timely manner needed to explain why they had failed to do so." Teachers attributed the non-involvement of their administrator in curriculum enrichment to the weaknesses of the overall educational system. They pointed out that government schools have no mechanism for monitoring teaching practices. As one of the teachers said, "In the government school, we (teachers) do not follow a certain curriculum. There is a specific curriculum for sixth graders, but we do not teach our students through a specific curriculum. We promote students to the next classes on the basis of their answering some typical questions."

Both the administrator and teachers admitted that the public educational system of Pakistan has certain weaknesses that minimize the quality of education in government schools. One of the weaknesses they identified was the absence of an affective accountability system. A teacher addressed the ineffectiveness of accountability as follows: The Annual Confidential Report (ACR) - an accountability tool in public schools-is toothless. No action is taken on the basis of these ACRs. . The ACRs ask the headmaster to mention the academic performance of students in the subjects of different teachers. . .If the performance of students is not good, the teachers do not receive a reprimand. The climate is not a conducive one for taking action. The administrator, who was frustrated with the poor attendance of his teachers, also attributed the non-serious attitude of teachers to the absence of accountability tool. Furthermore, the absence of community participation and the limited or non-involvement of district level educational officials in instructional affairs seemed to influence the practices of the administrator and teachers. On three occasions during the observation period, district educational officials visited the government school; yet, they neither visited classrooms to observe the teaching practices nor did they discuss issues pertaining to instruction and pedagogy with the administrator. Instead, they focused their attention on financial and administrative matters.

Discussion and analysis: Despite the fact that both administrators expressed their commitment to maintain the quality of education in their respective schools, a number of factors influenced the administrators' ability to succeed. Researchers agree that numerous variables, including organizational processes, staff characteristics, and size of organization, either support or hamper the daily business of school administrators (Hallinger \& Murphy, 1987; Peterson, 1987). Some of these variables also affected the daily business of the two subject administrators. Although the government administrator justified his limited involvement in the instructional processes to his expected transfer, it seemed that his reluctance to serve as the head of the government school was the primary reason for the poor status of his school. According to the government school administrator, an individual can either be a good administrator or an effective teacher, but not both. Although the administrator had a protracted teaching experience and was a subject specialist in the teaching of science subjects, he remained disengaged from the instructional processes of his staff. His behavior raises questions about his motivation to become an administrator. Unlike the government administrator, the community administrator tended to become more engaged in the instructional processes of his school. However, these engagements may have limited impacts upon the learning climate of the school. Two factors illustrate this: 1) the teachers' criticism of their administrator's practices and 2) the administrator's assumption that administrative tasks prevent him from playing an active role in instructional matters. The administrator had an impressive training background and enjoyed the continuous support of multiple actors, such as communities, Village Educational Committee, educational officials, vice principal and teachers. Yet, he seemed less motivated to participate in the classroom processes. I also did not observe the administrator spending a great deal of time on administrative tasks that would detract from his ability to improve the instructional quality of his school. However, on many occasions the administrator expressed his displeasure about the low salary package he and his staff received from the community school. The administrator was not explicit in linking his salary package with his limited involvement in the instructional processes, but it could be assumed that the low incentive might have made him less motivated. 
Although different circumstances affected the efficacy of both the community and government administrators, the two school leaders seemed less motivated to take care of their instructional responsibilities. Peterson (1987) pointed out that the success of instructional programs of schools depends upon the motivational level of administrators. He added that even if administrators have all the required skills and knowledge, their limited motivation could minimize their efficiencies. In the context of developing countries, researchers see the extrinsic factors as more important in enhancing the motivational level of educators (Papanastasiou \& Zambylas, 2004; Garret, 1999; Perry, Chapman, \& Snyder, 1995; Chivore, 1988); however, limited or no research examining the factors that influence the motivational level of school administrators in the context of Pakistan is available. This lack of research makes it difficult to develop assumptions about the factors that influence the performance of school administrators in Pakistan. In order to address this issue, empirical research needs to be conducted to explore and examine various dynamics that enhance or reduce the productivity of school administrators in Pakistani schools. The lack of motivation by the government administrator also reflects the recruitment procedure of Pakistani school administrator in which the length of teaching experience, not the individual's attitude, determines the appointment (Khan, 2012). Greenfield (1987) attributed the robustness of schools to the personal disposition of administrators: "The absence or presence of certain personal qualities may influence the ability of the individual to be effective in a specific work environment" (p. 58). Therefore, it might be beneficial to first determine the willingness of potential candidates before offering the job of headship. The existing practice of selection of administrators, which is based on length of teaching experience, needs to be revised. The new criteria might include the administrator's willingness to lead as well as his leadership qualities. The administrator of the community school demonstrated a strong understanding of the value of visiting classes, enriching curriculum, and arranging in-school professional development programs. Although he limited the nature of his class visits to ensuring the presence of teachers, he made certain efforts to ensure that the teachers focused on instruction. As a result, community teachers appreciated their administrator's involvement in in-school professional development programs and curriculum enrichment, despite their concerns about his overall performance. Since both the administrator and teachers were clear about the objectives of their school, a sense of harmony between the administrator and his staff motivated them to work together to achieve the goals of the school.

Unlike the community school, the government school lacked such a harmonious administrator/teacher relationship; therefore, the administrator made a limited contribution to the school's instructional processes. The absence of the administrator from the classroom practices, such as supervising teaching processes, providing feedback, and helping teachers to increase their capacities, led the government teachers to develop a low image of their administrator. Despite the fact the administrator had expertise in the teaching of science subjects; he did not transfer his pedagogical skills to his teachers because he assumed that they already had adequate training. When the government teachers reported that the students had unsatisfactory academic performances in science subjects, the administrator did not seem upset. The findings of this study suggest that both administrators contributed minimally to the instructional processes of their schools; however, the community administrator seemed better informed about the processes that could improve the teaching and learning environments. This better understanding resulted from the community administrator's job-related training and detailed job description. Various in-service programs helped him to differentiate between the concepts of leadership and management. Because of these opportunities, the administrator realized that instructional development was his primary responsibility. Unlike the community administrator, the government administrator neither had job-related training nor received a job description; he, therefore, was less clear about his managerial and instructional responsibilities. As a result, the government administrator focused on his administrative jobs and had only a minimal effect upon the teaching and learning processes of his school. Research suggests that any kind of change depends upon the transformation of individuals (Negroni, 2000); however, the Pakistani government paid little attention to such a transformation in terms of school leadership and its development, particularly in the government school system. Consequently, school administrators, especially those in government schools, make minimal contributions to the quality of education. Bush (2008) asserted that appointing administrators without adequate training is like gambling, "and it is inappropriate to gamble when the losers would be children or students" (p. 33). Evidence from Pakistan and other developing countries imply that the provision of professional development opportunities helped administrators to enhance their efficiencies in terms of the instructional development of their schools (Rizvi, 2008; Memon \& Bana, 2005; Fenech, 1994). Therefore, it might be beneficial for the administrators in 
Pakistan to receive proper orientation through pre- and in-service programs that could help them become more focused on the instructional dimensions of their responsibilities.

Another problem stems from the fact that neither the government school administrator nor teachers in Pakistan receive job descriptions at the time of their appointment. "The absence of job manuals and lack of defined roles make it very difficult to clearly assess the role of head teachers in Pakistan" (Khan, 2004. p. 81). Without a job description, educators, including the government administrator, do not always accurately interpret their responsibilities. Although the government administrator seemed aware of the purpose of education, he had a vague understanding about his responsibilities in terms of instruction and pedagogy. Likewise, some of the government teachers seemed less committed to their responsibilities, as illustrated by their high rate of absenteeism. While identifying different strategies for the leadership development program of less developing nations, Bush (2008) suggested, "Developing a clear job description, and linking candidates' experience to these requirements, provides a useful starting point" (p. 106). Therefore, the provision of a job description could help the administrators to differentiate between their instructional priorities and managerial responsibilities. Additionally, the provision of a job description could also serve as a tool of accountability for assessing the performance of administrators and teachers. One of the major differences between the internal structure of the community and government schools was that the community administrator, unlike the government leader, enjoyed the support of multiple stakeholders. The community administrator had a very good understanding that child development is a combined effort of the school and the parents/community (Owen, 2007). This conviction led him to involve the parents and community in the affairs of his school. For example, I often noticed that the community would identify potential volunteers who were ready to teach at the community school. The continuous support of these entities also resulted in the generating of resources, arranging of professional development programs, and supervising of teaching processes. Not only did the government administrator lack the support of parents and the community, but he also made no effort to secure the support of these entities. The School Management Committee in the government limited its role to signing financial documents. Research indicates that effective school administrators involve numerous stakeholders in order to achieve their objectives: "Skillful leaders work with representatives from the community to foster shared meaning, gather resources and support, and establish productive inter-organizational relationship" (Anderson, 2006. p.361).

While discussing the central role of communities and the progress of schools in less-developing countries, Tsang and Wheeler (1991) mentioned that communities could improve the quality of education through the establishment of a sustained relationship that contributes to the learning and provides necessary input. Researchers, who consider community support an essential requirement for developing quality schools, also believe that school administrators must possess certain skills that enable them to secure the maximum support of the parents and community (Coursen, 1981; Hoyle, English, \& Steffy, 1985; McEwan, 2003; Bolman \& Deal 2003). Therefore, school administrators need to receive specialized training that would prepare them to mobilize the parents and community for the development of the various component of education in their schools. According to Bush (2008), Western countries demonstrate this level of support in many areas, including the accountability processes of educators. The community administrator also benefited from the presence of an effective accountability tool; according to the government administrator and his teachers, their school had an ineffective accountability mechanism. While examining the impact of accountability on the performance of Pakistani private and government administrators, Khan (2005) pointed out that the accountability tool not only motivates the private administrator and his teachers, but also makes them more focused on their responsibilities. He added that the performance of the private school administrator and teachers determines their job tenure; however, the government school administrator and teachers do not worry that a poor performance will lead to their dismissal. This study also noticed such a pattern in which the community administrator and teachers, unlike their government counterparts, received certain indicators that played a role in their annual appraisal. These indicators motivated the teachers to effectively fulfill their responsibilities, even though their administrator had a limited role in the instructional processes of the school. Since such a mechanism was absent from government school, both the administrator and the teachers did not accept responsibility for the low academic environment of their school. Instead, the administrator criticized the country's educational system, and the teachers exhibited little confidence in the skills of their administrator. Unlike in the community school, the government school had no available indicators to evaluate the performance of the administrator and teachers. As a result, the administrator distanced himself from 
instructional practices, and the teachers were often absent from the school. Because both the administrator and teachers understood the limited effect of the Annual Confidential Report (ACR) - the accountability tool of the government school-they did not seem concerned; their apathy shaped their practices. While commenting on the weaknesses of ACRs, one of the Pakistani educational officials mentioned:

There are many loopholes in the mechanism of writing ACRs; these ACRs are written on the basis of likes and dislikes. This is a wrong approach, and it needs to be fixed. Regardless of the comments of the reporting officer, individuals still get their annual increments. On the basis of these ACRs, a strong performing teacher does not get a promotion, and an underperforming teacher does not receive a punishment or reprimand. (Khan, 2010, p. 197). Research suggests that developing countries cannot improve the quality of their education unless they introduce a strong accountability tool (ANSA, 2003; Khan, 2005). Peterson (1987), who favors the factor of control in the educational system, pointed out that such control must "insure that persons in the organization coordinate activities, cooperate on tasks, focus their energies and resources on organizational goals and are motivated to achieve those goals" (p. 140). Research also suggests that the salaries of educators need to be linked with the productivity of the educators because evidence shows that this payment/performance connection allows the private sector to thrive in Pakistan. Therefore, it is essential to introduce a system of checks and balances into the educational system of Pakistan in order to improve the quality of the country's educational system. Komatsu (2008) attributed the inefficacy of Pakistani government schools to the absence of an adequate level of monitoring by district level educational officials. This study noted a similar pattern in which the government educational officials were not instrumental in motivating the administrator to adopt a more instruction-oriented course; instead, they limited their instrumentalities to administrative measures. They did not participate in classroom visits or observe the teaching process. Many studies have also indicated that district level educational officials do not play an instrumental role in maintaining the quality of education in Pakistani government schools (Khan, 2004; Warwick \& Reimers, 1992; UNESCO, 1984; \& Nwankwo, 1983). Additionally, since the external actors and entities (federal, provisional, and district level educational officials) control the educational processes of government schools in Pakistan, school administrators tend to not play a proactive role, according to Simkins et al., (2003). As a result, government school administrators prefer to follow the directions from higher authorities than to initiate changes in their schools. However, as compared to government educational officials, community school educational officials were instruction-oriented; they frequently visited classrooms, participated in the development of the school's vision and objectives, and took an active role in teachers' appraisals. This involvement not only made more the community school administrator and teachers vigilant about their responsibilities, but it also gave the administrator the belief that his bosses supported his efforts. This involvement further led the educational officials of the community school to become better informed about the challenges and issues faced by administrator and teachers. According to Chapman (2002), efficient administrators at both the district and ministry levels played an important role in the educational development of some schools in Asian countries. Therefore, Pakistani government schools might benefit from having district level educational officials who receive more training and an evaluation of their performance. These officials need to be trained in a manner that would allow them to contribute to the instructional processes of schools, as noted in the case of private educational officials. Likewise, a mechanism needs to be developed which holds these officials accountable and responsible for their performances.

\section{Conclusion}

Numerous factors influence the quality of education in Pakistani public schools; one such element is the efficiency of school level administrators. According to the findings of this study, the efficiency of school administrators is contingent upon multiple elements, such as the provision of job related training, introduction of an effective accountability tool, support of instruction oriented educational officials, and contribution of parents/community. Therefore, the process of redefining the role of school administrators in Pakistan needs to properly address the above-mentioned elements. Although Pakistani educational policies have started acknowledging the centrality of school administrators, substantial efforts are still required to enable school administrators to contribute to the teaching and learning processes of their schools. 


\section{References}

Anderson, W. (2006). Engaging the public. In S.C. Smith, \& P.K. Piele (Eds.), School leadership. Hand book for excellence in student learning (4th Ed.). (pp. 359-379). Thousand Ok, CA: Sage Publications.

Andrabi, T., Das, J. \& Khwaja, A.I. (2008). A dime a day: the possibilities and limits of private schooling in Pakistan. Comparative and International Education Society, 52(3), 329-355.

ANSA. (2003). Social accountability imperative to a decent education system. Retrieved from http://www.ansafrica.net/index.php/views/feature_view/social_accountability_imperative_to_a_dece nt_education system/

Beatty, B. R. (2008). Theories of learning. In J. Lumby, G, Crow, \& P. Pashiardis (Eds.), International handbook on the preparation and development of school leaders (pp. 136-159). New York: Routledge Taylor and Francis.

Bolman, L. G. \& Deal, T. E. (2003). Reframing organizations. Artistry, choice, and leadership (3rd Ed.). San Francisco, CA: Jossey Bass.

Burki, J. S. (2005). Educating the Pakistani masses. In Hathaway, M.R. (Ed), Education reform in Pakistan: Building for the future. Washington, DC: Woodrow Wilson International Centre for Scholars.

Bush, T. (2008). Leadership and management development in education. Los Angeles: Sage Publications.

Chapman, D. (2002). Education in developing countries. Management and efficiency in education. Goals and strategies. Asian Development Bank, Comparative Education Research Center, the University of Honk Kong.

Chapman, D. W. (2000). Trends in educational administration in developing Asia. Educational Administration Quarterly, 36(2), 283-308.

Chivore, B. R. S. (1988). Factors determining the attractiveness of the teaching profession in Zimbabwe. International Review of Education, 34(1), 59-78.

Constas, M. A. (1992). Qualitative analysis as a public event: The documentation of category development procedures. American Educational Research Association, 29(2), 253-266.

Coursen, D. (1981). Communicating. In S.C. Smith, J. Mazzarella, \& P.K. Piele (Eds.), School leadership: Handbook for survival (pp.194-214). Eugene, Oregon: ERIC Clearing House on Educational Management, University of Oregon.

Douglas, A. (1988). Administration in less developed countries: Consideration for educators. The Journal of Educational Administration, 26(3), 367-381.

Fenech, J. M. (1994). Managing school in centralized system: Head teachers at work. Educational Management Administration and Leadership, 22(2), 131-139.

Garrett, R. M. (1999). Teacher job satisfaction in developing countries. DFID Publication. ERIC.

Greenfield, W. (1987). Moral imagination and interpersonal competence: antecedents to instructional leadership. In: Greenfield, W. (Ed.), Instructional Leadership: Concepts, Issues, and Controversies. Boston, MA: Allyn and Bacon, Inc.

Hallinger, P. \& Murphy, J. (1987). Instructional leadership in the school context. In: Greenfield, W. (Ed.), Instructional leadership: Concepts, issues and controversies. Boston, MA: Allyn and Bacon, Inc

Hoyle, J. R., English, F. \& Steffy, B. (1985).Why are some administrators more successful than others? Skills for successful school leadership. Arlington, VA: The American Association of School Administrators.

Jimenez, E. \& Lockheed, M. E. (1995). Public and private secondary education in developing countries. A comparative Study. Washington, DC: The World Bank.

Kandasamay, M. \& Blaton, L. (2004). School Principals: Core actors in educational improvement, an analysis of seven Asian countries school. Paris: International Institute for Educational Planning.

Khaki, J. A. (2005). Exploring the beliefs and behaviors of effective head teachers in the government and nongovt schools in Pakistan (PhD dissertation). Retrieved from ProQuest database (AAT. NRO 2738)

Khan, A. (2010). A case study exploring perceived professional development needs for secondary school administrators in Pakistan. Unpublished PhD dissertation. Administrative and Policy Studies, School of Education, University of Pittsburgh, Pennsylvania.

Khan, A. (2012). Instructional management of a private and a government secondary school principal in Northern Pakistan. International Journal of Educational Management, 32(1), 120-131.

Khan, H. (2004). Better school management in the Islamic Republic of Pakistan: The role of head teacher. In M. Kandasamay \& L.Blaton (Eds.), School Principals: Core actors in educational improvement, an analysis of seven Asian countries (pp.59-113). Paris: International Institute for Educational Planning. 
Khan, S. R. (2005). Basic education in rural Pakistan. A comparative institutional analysis of government private and NGO schools. Karachi: Oxford University Press.

Komatsu, T. (2008). Qualitative inquiry into local education administration in Pakistan. International Journal of Educational Development, 29(3), 219-226.

Legotlo, M. \& Van der Westhuizen, P. C. (1996). Coming on board: problems facing new principals in developing countries. Educational Management and Administration, 24(4), 401-410.

McEwan, E. K. (2003). 7 Steps to effective instructional leadership (2nd Ed). Thousand Oaks, CA: A Sage Publications.

Memon, M. (2000). Preparing school leaders for the 21st century Pakistan. Paper presented at the International Congress for School Effectiveness and Improvement: Global Networking for Quality Education in Hong Kong, January 4-8.

Memon, M. (2000). Re-conceptualizing the role of head teachers as pedagogical leaders in Pakistan: Implication for policy reforms. Education, 3(12), 6-10.

Memon, M. \& Bana, Z. (2005). Pedagogical leadership in Pakistan: Two head teachers from the Northern Areas. In J. Retallick, \& I. Farah (Eds.), Transforming schools in Pakistan. Towards the learning community. Karachi: Oxford University Press.

Memon, M., Ali, R. N., Simkins, T. \& Garrett. (2000). Understanding the head teacher's role in Pakistan: A case study. International Studies in Educational Administration, 28(2), 48-56.

Mertens, D. M. (2005). Research and evaluation in education and Psychology (2nd Ed). Thousand Oaks: Sage publications.

Negroni, P. (2000). The superintendent's progress. In P. Senge., N.C. McCabe; T. Lucas., B. Smith; J. Dutton; A. Kleiner. Schools that learn. A fifth discipline field book for educators, parents, and everyone who cares about education (pp.425-432). New York, New York: Doubleday Publishing.

Nwankwo, J. I. (1983). Strengthening educational institutions in Sind and Punjab province. Paris: UNESCO.

Ogawa, R. T. \& Malen, B. (1991). Towards rigor in review of multivocal literatures. Applying the exploratory case study method. Review of Educational Research, 61(3), 265-286.

Oplatka, I. (2004). The principals in developing countries: Context, characteristics and reality. Comparative Education, 40(3), 428-448.

Owen, H. (2007). Creating leaders in the classroom. How teachers can develop a new generation of leaders. New York: Routledge Taylor \& Francis.

Papanastasiou, E. \& Zembylas, M. (2005). Job satisfaction among school teachers in Cyprus. Journal of Educational Administration, 42(3), 357-374.

Perry, P. D., Chapman, D. W. \& Snyder, C. W. (1995). Quality of teacher work_life and classroom practices in Botswana. International Journal of Educational Development, 15(2), 115-125.

Peterson, K. D. (1987). Administrative control and instructional leadership. In: Greenfield, W. (Ed.), Instructional leadership: Concepts, issues, and controversies. Boston, MA: Allyn and Bacon, Inc.

Plank, D. N. (1987). School administration and school reforms in Botswana. International Journal of Educational Development, 7(2), 119-126.

Rizvi, M. (2008). The role of school principals in enhancing teacher professionalism: Lessons from Pakistan. Educational Management Administration and Leadership, 36(1), 85-100.

Simkins, T., Garret, V., Memon, M. \& Ali, R. N. (1998). The role perception of government and non-government head teachers in Pakistan. Educational Management and Administration, 26(2), 131-146.

Simkins, T., Sisum, C. \& Memon, M. (2001). School leadership in Pakistan: Exploring the head teachers' role. School Effectiveness and School Improvement.

Simkins, T., Sisum, C. \& Memon, M. (2003). School leadership in Pakistan: Exploring the head teachers' role. School Effectiveness and School Improvement.

Stake, E. R. (1995). The art of case study research. Thousand Oaks: Sage Publications.

Tsang, M. C. \& Wheeler, C. (1991). Local initiatives and their implications for a multi-level approach to school improvement in Thailand. In H.M Levin \& M.E Lockheed; Effective schools in developing countries (pp.122-46). Washington, DC: The Falmer Press

UNESCO. (1984). Diagnostic studies on educational management. Case studies Pakistan. Bangkok: UNESCO.

Warwick, D. P. \& Reimers, F. (1995). Hope or Despair: Learning in Pakistan's primary schools. CT: Praeger Publisher. 